\title{
Fire Technology Guest Editorial: Special Section on Fire Literafure and Information
}

\author{
Mike Culhane*, Library/Internet Services, Institute for Research \\ in Construction, National Research Council Canada, \\ Ottawa, ON, Canada
}

"It is a very sad thing that nowadays there is so little useless

information.'

Oscar Wilde

(Saturday Review, Nov. 17, 1894)

Although no doubt spoken tongue-in-cheek, I suspect that Oscar Wilde might have a different opinion were he alive today, because the Internet has made useless information an epidemic.

In 2012, finding useless information is easy. But finding reliable, authoritative, meaningful information? Now that's hard. These days we're assaulted by information from everywhere, and with such volume and speed that it's impossible to absorb even a fraction of the amount we encounter each day, never-mind determining which bits are actually relevant to our daily lives. When it comes to finding information we need, the expression "drinking from a fire hose" has never been more apt.

If you happen to work for an innovative, forward-thinking organization, where the value of information and its importance to success is well understood, consider yourself lucky. You probably have at your disposal a corporate library and at least one librarian (a.k.a. Information Specialist, Knowledge Manager, Cybrarian, Information Broker, etc.).

These aren't your grandmother's libraries, mind you. If you are imagining a quaint place where books go to collect dust, protected by a shushing, hair-bunwearing matron, think again. Modern corporate libraries are like hive-minds; acquiring, filtering, synthesizing and distributing information where it's needed most, keeping organizations vital and relevant. They are staffed by experts with graduate degrees in Library and Information Science, who know the ins and outs of searching the Internet and commercial literature databases. (These are the people who actually use obscure search operators.) They find information ranging from refereed literature to codes and standards to patents and market intelligence. Some manage vast virtual libraries containing no physical documents at all.

In an age where separating good information from the irrelevant is increasingly difficult, libraries and librarians are more crucial than ever. Far from being

\footnotetext{
* Correspondence should be addressed to: Mike Culhane, E-mail: Mike.Culhane@nrc-cnrc.gc.ca
} 
outmoded, the principles and practices of library science continue to influence and shape the Internet. Google, in fact, grew out of the Stanford Digital Library Project and its page ranking system is based on citation indexing, a tool used by librarians years before the founders of Google were even born.

The Internet is an incredible resource that has helped make information more accessible. But "accessible" does not necessarily mean "findable." Simply digitizing a document and putting it on the Web is not enough - without context it's just more noise. Moreover, the perception that everything is on the Internet is a myth. Even if it were true, most of it could not be searched, because despite the fact that Google has more than a trillion URLs in its database, "the "deep web" or "invisible web" (information buried in databases and applications that search engines can't index) is estimated to be as much as 500 times bigger. ${ }^{2}$ In its first seven years of operations, Google CEO Eric Schmidt admitted that Google had only indexed $.004 \%$ of all the information available on the Internet. Seven hundred thousand pages are added every minute, so even if the Internet shut down right now, it would take Google another three hundred years to index it all. ${ }^{3}$

Personalization has made it even more difficult to find objective information. Search results can be affected by everything from where you are sitting to the kind of browser you are using. The search you do today might generate different results from the same search next week, and will definitely be different from those of your colleague in another city. Google apparently uses 57 signals to tailor the search results page specifically to you. ${ }^{4}$ Much of the time this is a good thing (if I am in Boston and search "Mexican restaurants" I probably want to see restaurants near me, not those in Vancouver), but it also raises the question "What am I missing?" Personalization limits our access to information, and we may not even know it. Eli Pariser calls this troubling concept the "filter bubble". 5

Fortunately, librarians understand how search engines work and how to get around the problem of filtering. They also know that everything is not on the Internet and, most importantly, they can actually speak to the requester. People often don't know how to ask the right questions to get the answers they are seeking. Person-to-person communication leads to a better understanding of the request by both parties and better information for the requestor. Old fashioned? Maybe, but no computer or search engine can do that (yet!).

As a reader of Fire Technology, you may work for an organization that has a library, and most likely it is a member of inFIRE (the International Network for

\footnotetext{
${ }^{1}$ Jesse Alpert \& Nissan Hajaj, Software Engineers, Web Search Infrastructure Team, Google Inc., "We knew the web was big..." The Official Google Blog, July 25, 2008. http://googleblog.blogspot. com/2008/07/we-knew-web-was-big.html.

${ }^{2}$ Gary Price, Chris Sherman, The Invisible Web: Uncovering Information Sources Search Engines Can't See (Medford, N.J.: CyberAge Books, Information Today, c2001), p. 311.

${ }^{3}$ Thomas H. Forthe, "How Big is the Internet, and How Does One Measure a World Wide Phenomenon?" May 12, 2009. http://www.associatedcontent.com/article/1728454/how_big_is_the_internet_and_ how_does.html?cat $=15$.

${ }^{4}$ René Pickhardt, "What are the 57 signals google uses to filter search results?" May 17, 2011. http://www.rene-pickhardt.de/google-uses-57-signals-to-filter/.

${ }^{5}$ Eli Pariser, "Beware online "filter bubbles", March 2011. http://www.ted.com/talks/eli_pariser_ beware_online_filter_bubbles.html.
} 
Fire Information and Reference Exchange-www.infire.org). InFIRE is a global consortium of libraries and information centers with significant collections of fire literature. Members converse online and meet annually to share information and gather knowledge about the latest technology and trends in fire research, fire protection engineering and information management.

This special issue of Fire Technology contains a selection of papers from inFIRE members. I hope you enjoy them, and if you haven't visited your local library recently (either in person or remotely), I encourage you to do so. With apologies to Oscar Wilde, you just might be surprised by how little useless information you'll find there-especially if you consult a librarian. 